Short communication

\title{
IGF1 GENE POLYMORPHISM IN SELECTED SPECIES OF THE CANIDAE FAMILY
}

\author{
JAKUBCZAK Andrzej, GRYZINSKA Magdalena*, HORECKA Beata, \\ JEZEWSKA-WITKOWSKA Grazyna
}

Department of Biological Basis of Animal Production, Faculty of Animals Biology and Breeding, University of Life Sciences in Lublin, ul. Akademicka 13, 20-950 Lublin, Poland

(Received 14 October 2016, Accepted 03 February 2017)

The gene IGF1 has been shown to have a significant influence on the size of individuals, including animals of the Canidae family. In this study we determined SNP mutations of the IGF1 gene in dogs, raccoon dogs and farmed and free-living red foxes from Poland and Canada. No SNP mutations were noted in dogs or raccoon dogs, but a total of 14 single nucleotide polymorphisms were identified in foxes, including 12 substitutions, as well as one new mutation missense variant (exon 6) in wild Polish foxes and one synonymous mutation variant in wild foxes from Canada. We identified specific SNP profiles characteristic only for farmed foxes and only for wild foxes, as well as specific SNP profiles or wild foxes from North America (Canada) and from Europe (Poland).

Key words: IGF1, SNP, dog, fox, raccoon dog

\section{INTRODUCTION}

The Canidae are a family of over thirty currently living species, differing substantially in size. Among many genes influencing the size of individuals, an important role is played by IGF1 (insulin-like growth factor 1, somatomedin C), which encodes specific proteins whose structure and function are similar to that of insulin and which are included in the family of proteins having a significant effect on growth and development [1]. The production of proteins with properties similar to those of insulin is stimulated by the activity of growth hormone $(\mathrm{GH})$ in the liver. In response to $\mathrm{GH}$ activity, liver cells induce a protein called insulin-like growth factor 1 (IGF-1) to be produced [2]. This protein stimulates skeletal growth and cell maturation in numerous tissues, as well as the processes of chondrogenesis and osteogenesis in cartilage of bones [3]. IGF-1 affects hormone metabolism and regulates the growth of many tissues through preand postnatal autocrine/paracrine activity. It stimulates growth by binding and activating transmembrane tyrosine kinase receptors (IGF-1R). The complex of

*Corresponding author: e-mail: magdalena.gryzinska@up.lublin.pl 
IGF-1 and IGF-1R causes autophosphorylation of the cytoplasmic domain, which in turn initiates a signal transmission cascade, leading to increased growth [4-6]. It has been shown that the more protein produced by the IGF1 gene is contained in the blood, the larger the individual. Mice with a damaged IGF1 gene have been shown to attain a very small size, while humans with a deletion in this gene are born with a body length considerably below the norm [7]. The IGF1 gene has a substantial effect on the size of individuals in some breeds of pig [8], cattle [9], as well as in canids $[10,11]$. Single nucleotide polymorphism is a very good molecular marker enabling characterization of nucleotide variation between wild and farmed individuals.

The aim of the study was to determine the nucleotide sequence of fragments of the IGF1 gene in farmed and wild individuals of the Canidae family, and to identify any polymorphisms occurring in the nucleotide sequence. This will provide a better understanding of the role of this gene in heredity of morphometric traits in species of this family.

\section{MATERIAL AND METHODS}

DNA was isolated from a total 125 samples - from the blood of dogs - 25 samples, farmed raccoon dogs - 25 samples (from Poland), and farm red foxes (Vulpes vulpes) - 25 samples (from Poland), and from raw skins of wild foxes (25 samples from Poland and -25 samples Canada), using a QIAgen commercial extraction kit (QIAamp DNA Blood Mini Kit or Kit-DNeasy Blood \&Tissue Kit) according to the producer's instructions. There were 25 individuals in each group. The gene IFG1 (insulin-like growth factor 1), (NCBI ID: 610255) was examined. The primers (F: AAGTAGCCTGAGTAAGATTTGACT and R: AGCAATCTACCAACTCCAGGACCA) were designed using Primer3Plus software [12] to amplify a region of IGF1 (exon 6). The first amplification was performed using Ampli Taq Gold 360 DNA Polymerase (Applied Biosystems). The second amplification (sequencing PCR) - bidirectional sequencing - was carried out using the BigDye ${ }^{\circledR}$ Terminator v3.1 CycleSequencing Kit (Applied Biosystems) procedure (Labcycler, SensoQuest). PCR products were purified in a biorobot (QIAcube) using a DyeEx Spin Kit (Qiagen). PCR products were sequenced using a 3100-Avant Genetic Analyzer (Applied Biosystems). Sequencing results were aligned using BLAST. The sequencing data were then compared with the dog (NC_006597.3) sequences registered in the NCBI database. The SNP positions of wild and farmed individuals were compared using MEGA4. Individual SNP profiles frequencies were calculated using the SAS statistical package. An SNP profile was defined as a set of single nucleotide polymorphisms (SNPs) obtained by sequencing with respect to each of the gene fragments investigated.

\section{Statistical analysis}

The chi-square test for goodness of fit between observed and predicted genotype frequencies was employed to test Hardy-Weinberg. 
The protocol was approved by the 2nd Lublin Local Ethical Commission for Animal Experiments (Permit Number 83/2009 of 08/12/2009).

\section{RESULTS AND DISCUSION}

The length of the IGF1 fragment examined was $419 \mathrm{bp}$ in the dog, $393 \mathrm{bp}$ in the raccoon dog and $305 \mathrm{bp}$ in the fox. SNP was noted only in the fox. Among 19 individuals (8 wild Polish, 5 wild Canadian and 6 farmed), 14 single nucleotide polymorphisms (SNPs) were detected (Figure 1), including eight transitions, at positions c.8071, c.8283 and c.8290 (A>G), c.8178 and c.8366 (G>A), c.8226 (T>C), c.8278 (C>T) and c.8314 $(\mathrm{T}>\mathrm{C}, \mathrm{Y})$, and six transversions, at c.8066 and c.8232 (T>A), c.8077 (G>T), c.8281 and c.8307 (G>C) and c.8358 (C>A). A change at position 8232 caused a serine-toarginine amino acid change (p.S198R).

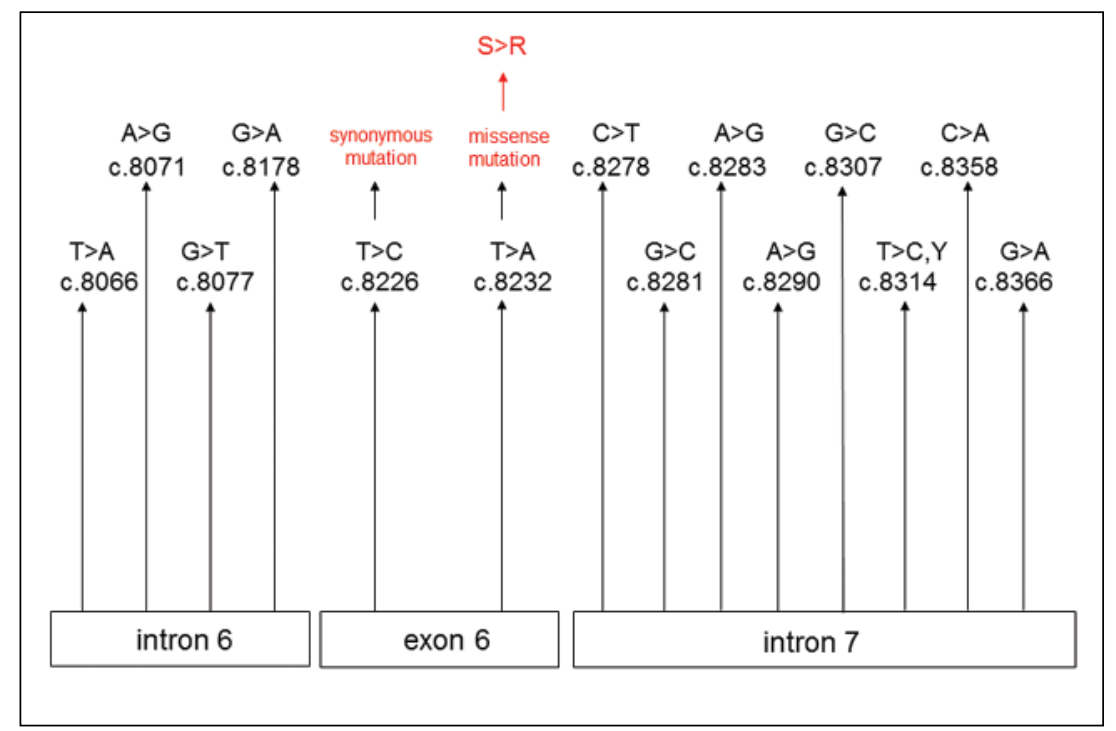

Figure 1. Localization SNPs in IGF1 gene (Vulpes vulpes). In red: mutation in exon 6 - missense mutation and synonymous mutation

The analysis showed 8 SNP profiles (A-H) (Table 1). Profiles A, C, D and G were present only in wild Polish individuals. Wild Canadian foxes had profiles B and H. Only farmed individuals had profile F, which may be an indication of selective breeding aimed at obtaining varieties with particular body dimensions that would not have arisen in natural conditions. Profile $\mathrm{E}$ was present in all individuals, suggesting that this mutation is inherited in both farmed and wild animals [13,14].

The completion of the dog genome sequencing project has made it possible to find SNPs in the genomes of animals of the Canidae family. Sacks and Louie [15] used various primer pairs designed using random fragments of the dog genome to sequence 
$80-88 \%$ of loci in the coyote (Canis latrans), the gray wolf (Urocyon cinereoargenteus) and the red fox (Vulpes vulpes). The presence of SNP profiles noted only in farmed foxes or only in wild foxes may be due to the animals' different living conditions, and may also be an indication of selective breeding making it possible to obtain varieties with particular traits which would not have arisen in natural conditions.

Table 1. The types and frequencies of SNP profiles in the IGF1 gene of foxes

\begin{tabular}{|c|c|c|c|c|c|}
\hline \multirow{2}{*}{ Gene } & \multirow{2}{*}{$\begin{array}{c}\text { SNP } \\
\text { profiles }\end{array}$} & \multirow{2}{*}{$\begin{array}{l}\text { Frequency of } \\
\text { SNP profiles }\end{array}$} & \multicolumn{3}{|c|}{ Frequency of SNP profiles } \\
\hline & & & Farm & Wild (Poland) & Wild (Canada) \\
\hline \multirow{8}{*}{ IGF1 } & $\mathrm{A}$ & 0.04 & & 0.12 & \\
\hline & B & 0.05 & & & 0.16 \\
\hline & $\mathrm{C}$ & 0.04 & & 0.12 & \\
\hline & $\mathrm{D}$ & 0.04 & & 0.12 & \\
\hline & $\mathrm{E}$ & 0.67 & 0.80 & 0.52 & 0.68 \\
\hline & $\mathrm{F}$ & 0.07 & 0.20 & & \\
\hline & G & 0.04 & & 0.12 & \\
\hline & $\mathrm{H}$ & 0.05 & & & 0.16 \\
\hline
\end{tabular}

The alleles' frequencies were in Hardy-Weinberg equilibrium.

SNPs were noted in the amplified IGF1 gene fragments. Specific SNP profiles characteristic only for farmed foxes and only for wild foxes were obtained. At the same time, specific SNP profiles were noted for wild foxes from North America and from Europe. The diversity of phenotypes occurring among wild and farmed animals is a significant factor enabling variation between species and groups of animals [14].

\section{Acknowledgements}

This research was supported and funded by the National Centre for Research and Development (NCBiR), development project no. 12-0140-10.

\section{Authors' contributions}

JA authorship of the research hypothesis (the idea of the experiment), a lead role in planning the experiment, the choice of animal material for the research, collection of data necessary for the statistical analysis. GM, HB and JWG participated in analysis of the results and preparation of the manuscript for publication. All authors read and approved the final manuscript.

\section{Declaration of conflicting interests}

The author(s) declared no potential conflicts of interest with respect to the research, authorship, and/or publication of this article. 


\section{REFERENCES}

1. Gray MM, Sutter NB, Ostrander EA, Wayne RK: The IGF1 small dog haplotype is derived from Middle Eastern grey wolves. BMC Biology 2010, 8:16.

2. Schwander JC, Hauri C, Zapf J, Froesch ER: Synthesis and secretion of insulin-like growth factor and its binding protein by the perfused rat liver: dependence on growth hormone status. Endocrinology 1983, 113:297-305.

3. Favier PR, Mol AJ, Kooistra SH, Rijnberk A: Large body size in the dog is associated with transient GH excess at a young age. J Endocrinol 2001, 170:479-84.

4. Khandwala HM, McCutcheon IE, Flyvbjerg A, Friend KE: The effects of insulin-like growth factors on tumorigenesis and neoplastic growth. Endocrine Rev 2000, 21:215-44.

5. Pollak MN, Schernhammer ES, Hankinson SE: Insulin-like growth factors and neoplasia. Nat Rev Cancer 2004, 4:505-18.

6. Brisson BK, Barton ER: New modulators for IGF-I activity within IGF-I processing products. Front Endocrinol 2013, 4:42.

7. Elis S, Courtland HW, Wu Y, Rosen CJ, Sun H, Jepsen KJ, Majeska RJ, Yakar S: Elevated Serum Levels of IGF-1 Are Sufficient to Establish Normal Body Size and Skeletal Properties Even in the Absence of Tissue IGF-1. J Bone and Miner Res 2010, 25:1257-66.

8. Niu P, Kim WS, Choi HB, Kim HT, Kim JJ, Kim SK: Porcine insulin-like growth factor 1 (IGF1) gene polymorphisms are associated with body size variation. Genes Genome 2013, 35:523-528.

9. Mullen PM, Berry PD, Howard JD, Diskin GM, Lynch OC, Giblin L, Kenny AD, Magee AD, Meade GK, Waters MS: Single nucleotide polymorphisms in the insulin-like growth factor 1 (IGF-1) gene are associated with performance in Holstein-Friesian dairy cattle. Front Gene 2011, 2:3.

10. Sutter NB, Bustamante CD, Chase K, Gray MM, Zhao K, Zhu L, Padhukasahasram B, Karlins E, Davis S, Jones PG, Quignon P, Johnson GS, Parker HG, Fretwell N, Mosher DS, Lawler DF, Satyaraj E, Nordborg M, Lark KG, Wayne RK, Ostrander EA: A single IGF1 allele is a major determinant of small size in dogs. Science 2007, 316:112-5.

11. Wayne RK, Ostrander EA: Lessons learned from the dog genome. Trends Genet 2007, 23:557-67.

12. Rozen S, Skaletsky H: Primer3 on the WWW for general users and for biologist programmers. Methods Mol Biol 2000, 132:365-86.

13. Gugolek A, Strychalski J, Konstantynowicz M, Zwolinski C: Comparative analysis of nutrient digestibility and nitrogen retention in wild and farmed canids. Ann Anim Sci 2014, 14:307-314.

14. Jakubczak A, Gryzińska M, Horecka B, Kasperek K, Dziadosz K, Jeżewska-Witkowska G: Genetic differentiation of common fox Vulpes vulpes (Linnaeus, 1758) on the basis of the insulin-like growth factor 1 (IGF1), myosin-XV (MYO15A) and paired box homeotic 3 (PAX3) genes fragments polymorphism. Ann Anim Sci 2014, 14:807-819.

15. Sacks B, Louie S: Using the dog genome to find single nucleotide polymorphisms in red foxes and other distantly related members of the Canidae. Mol Ecol Res 2008, 8:35-49. 


\title{
POLIMORFIZAM IGF1 GENA U ODABRANIM VRSTAMA KANIDA
}

\author{
JAKUBCZAK Andrzej, GRYZINSKA Magdalena, HORECKA Beata, \\ JEZEWSKA-WITKOWSKA Grazyna
}

IGF1 gen značajno utiče na veličinu tela, uključujući i vrste Canidae familije. U studiji je obavljeno ispitivanja SNP mutacija IGF1 gena kod pasa, rakuna, lisica u uzgoju i u slobodnoj prirodi na teritoriji Poljske i Kanade. Nisu ustanovljene SNP mutacije kod pasa ili rakuna ali je uočeno 14 jediničnih polimorfizama nukleotida kod lisica, koji su obuhvatali 12 substitucija kao i jednu novu mutaciju (exon 6) kod divljih lisica u Poljskoj i jednu sličnu mutaciju kod divljih lisica Kanade. Identifikovani su specifični SNP profili koji su karakteristični samo za lisice koje se drže u uzgoju kao i za lisice na slobodi. Isto tako identifikovani su specifični SNP profili divljih lisica Severne Amerike (Kanade) i u Evropi (Poljska). 